\title{
RESPONSE TO CHALLENGES IN CURBING SELECTED WILDLIFE POACHING DURING COVID-19 LOCKDOWN
}

\author{
RAHIMATSAH AMAT ${ }^{1}$ AND MOHD TAJUDDIN ABDULLAH*2,3 \\ ${ }^{1}$ Sabah Environmental Trust, Lot F-4-9, Plaza Tg Aru, Jalan Mat Salleh, 88100 Kota Kinabalu, Sabah, Malaysia. ${ }^{2}$ Faculty of \\ Fisheries and Food Science, Universiti Malaysia Terengganu, 21030 Kuala Nerus, Terengganu, Malaysia. ${ }^{3}$ Fellow Academy \\ of Sciences Malaysia, Level 20, West Wing, Tingkat 20, Menara MATRADE, Jalan Sultan Haji Ahmad Shah, 50480 Kuala \\ Lumpur, Malaysia.
}

*Corresponding author: mohd.tajuddin@umt.edu.my

Submitted final draft: 4 October $2020 \quad$ Accepted: 25 December $2020 \quad$ http://doi.org/10.46754/jssm.2021.10.001

The global COVID-19 outbreak started in Wuhan, China (Lu et al., 2020; WHO, 2020) and the movement control order (MCO) (PMO, 2020a) is showing certain impacts on wildlife conservation (Abdullah et al., 2020; Amat et al., 2020; Goldman, 2020; Ten et al., 2021). In this letter to the editor, we highlight our concerns on selected species conservation issues and suggest ways for the readiness and preparedness of future disasters that are potentially impacting endangered wildlife species. The wildlife authorities in Sabah had approved the use of surveillance cameras since 2017. These surveillance cameras are deployed at several hotspots in DaMaI Rainforest Complex (c. 1.0 million hectares) in Sabah, primarily to monitor encroachment or other illegal activities, and to complement the efforts to monitor wildlife movements and distributions in the forest reserves. The cameras utilised cellular networks and are able to transmit triggered images within 30 seconds to dedicated contacts (either email or SMS to handphones). The exact locations are not revealed to protect the habitats and endangered species. Based on images from selected remote surveillance cameras during $\mathrm{MCO}$, some endangered species were easily recorded utilising the forest edges for foraging or moving between forests (Figure 1). Consequently, this situation exposed selected endangered species of wildlife to be exploited by poachers for the lucrative bush-meat trade. During the MCO period, while it was observed that illegal activities were significantly reduced, there were incidents of poaching. Images from surveillance cameras provided crucial information on movements of poachers that eventually led to several arrests by the authorities in DaMaI Rainforest Complex (Astroawani1, Astroawani2 \& Star).

The Federal government had allocated about RM260 billion for economic stimulus (PMO. 2020b). Evidently, lack of funding was allocated for environmental and biodiversity protection programs. Therefore, we strongly urge the federal and state governments to provide improved funding, equipment, support systems and trained personnel for wildlife authorities to increase $24 \times 7$ surveillance capacity in forested state lands, forest reserves and protected areas. Local NGOs could also be involved to provide valuable real-time information and cameratrapping data for wildlife authorities to take swift action to arrest poachers and intruders in the wildlife habitats. Finally, we would recommend that all wildlife conservation areas in Malaysia to be constantly on $\mathrm{MCO}$ from $7 \mathrm{pm}$ to $7 \mathrm{am}$ from now onwards to safeguard our natural capital. 


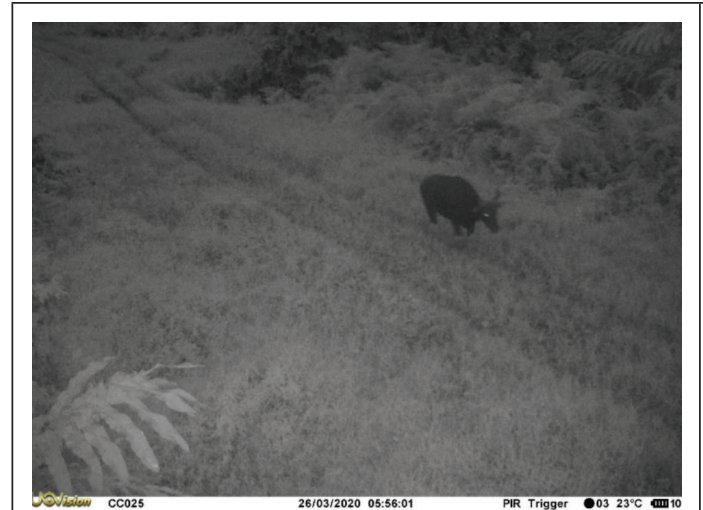

1a. Tembadau or Banteng is a threatened species in Malaysia.

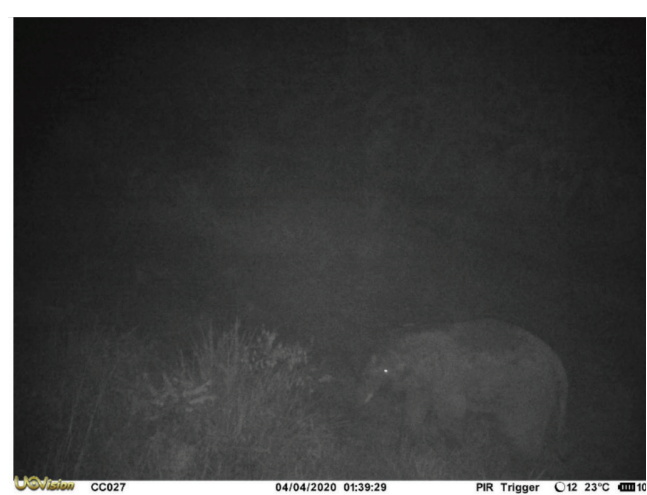

1c. The endangered elephants using a service road.

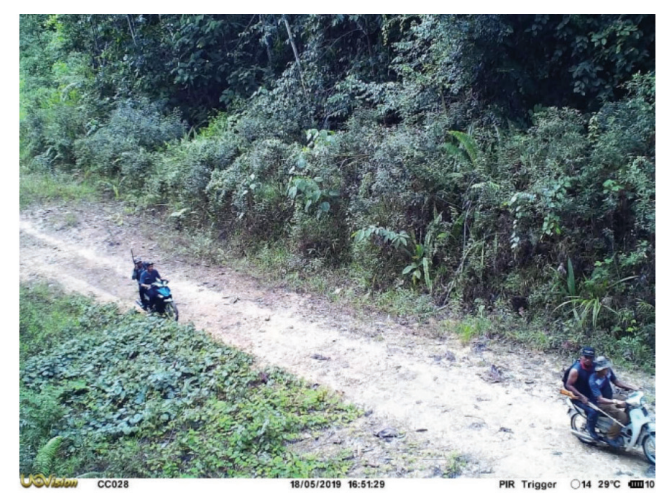

1e. Poachers caught on wildlife surveillance camera in the forest before the MCO.

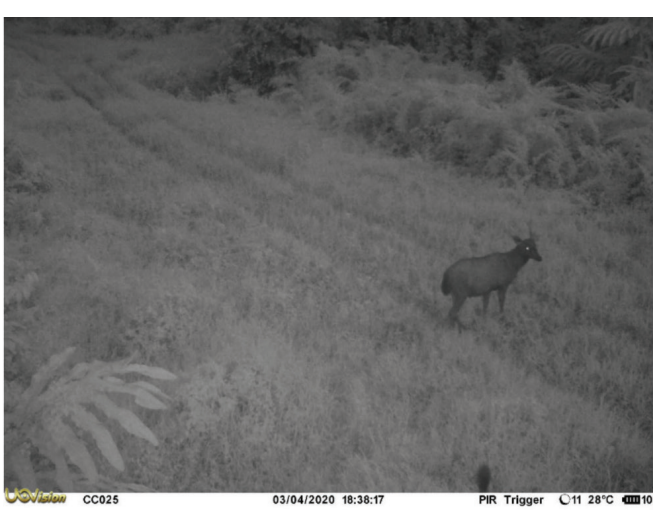

1b. Sambar deer utilising the service road in the forest. The population is declining in Malaysia.

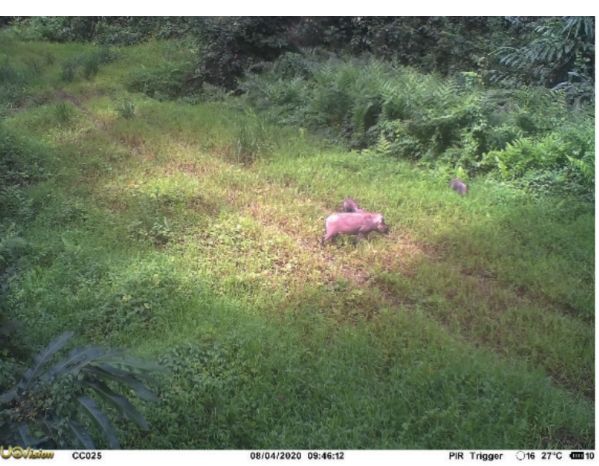

1d. Wild pigs foraging on a service road and forest fringes. The wild pig population is important to keep a healthy wild cats population in our forest.

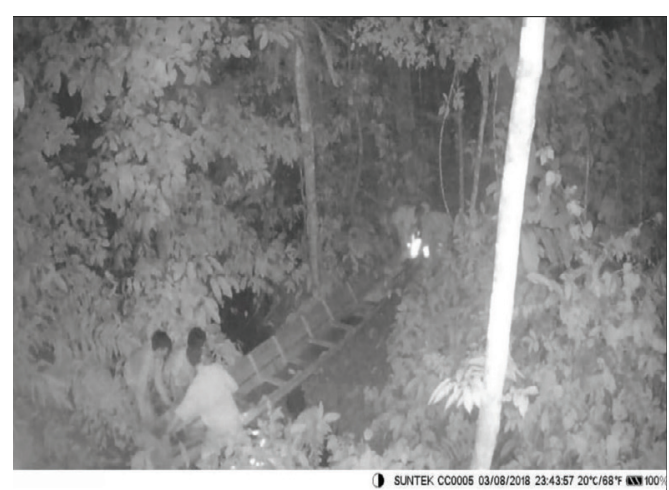

1f. Illegal caught on a wildlife surveillance camera in the forest before the MCO. 


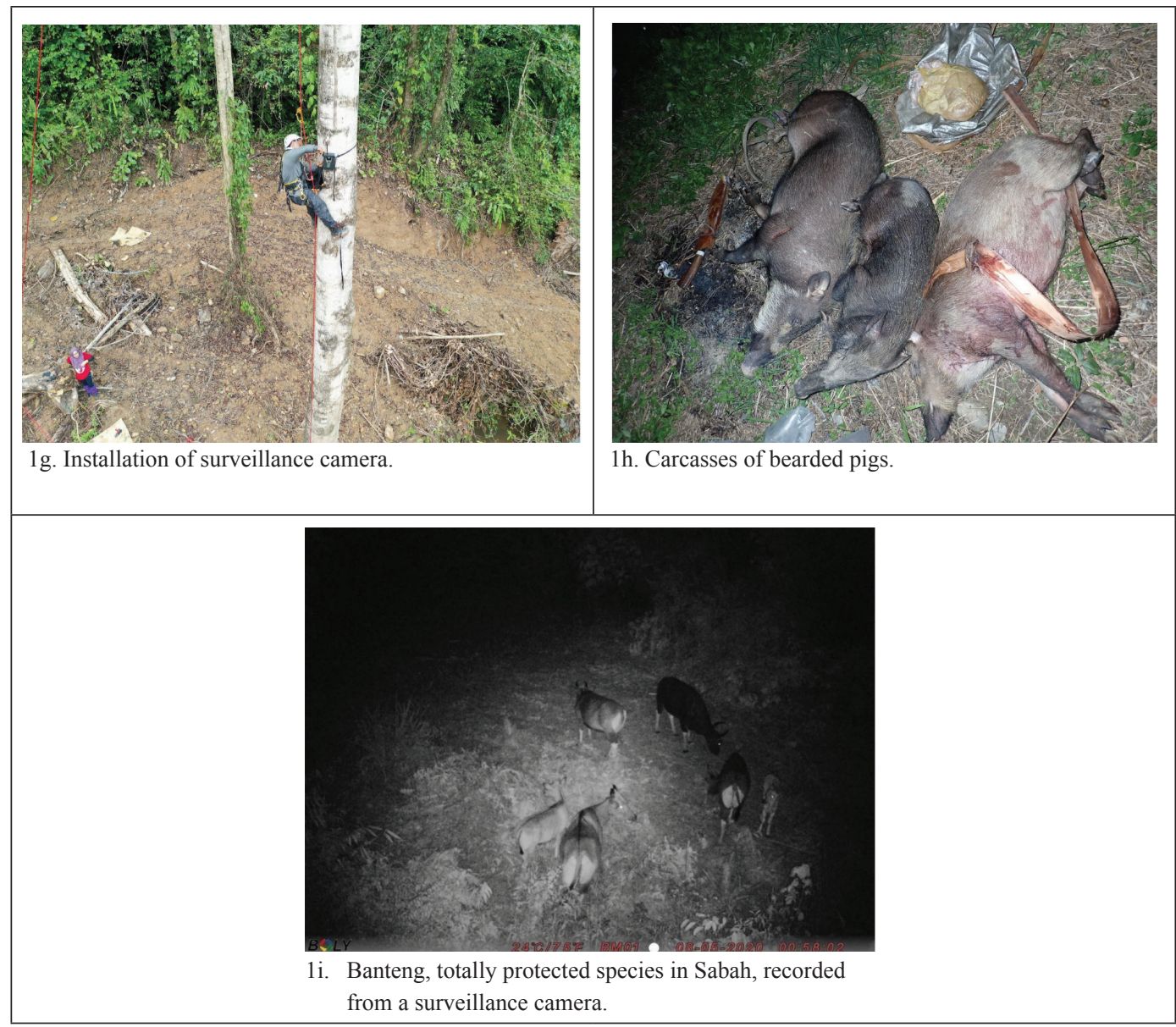

Figure 1: Some of the endangered wildlife species that could be seen in forested areas in Malaysia (a, b, c). Figures $1 \mathrm{e}$ and $1 \mathrm{f}$ show the images of poachers in the wildlife habitat before the MCO. It is imperative that our natural treasures be protected and well managed at all costs by the federal and state government

\section{References}

Abdullah, M. T., Edinur, H. A., \& Yung, D. T. C. (2020). COVID-19 and the emergence of zooanthroponisis. UMT Academic Affairs Quick Update, 50, 1-2.

Amat, R., Abdullah, R., \& Abdullah, M. T. (2020). Harnessing MCO for SDG15. UMT Academic Affairs Quick Update, 51, 5-6.

Astroawani1. (March 2020). http://www. astroawani.com/berita-malaysia/ketikarakyat-diseru-duduk-rumah-sekumpulanpemburu-haram-sasarkan-hidupan-liar-dihutan-234917
Astroawani2. (May 2020). https://beta. astroawani.com/berita-malaysia/dualelaki-tempatan-pemburu-haram-ditahanbersama-senjata-api-241938

Goldman., J. G. (2020). How the coronavirus has changed animals' landscape of fear. Access on May 21st, 2020.https://www. scientificamerican.com/article/howthe-coronavirus-has-changed-animalslandscape-of-fear/

Lu, R., Zhao X., Li, J., Niu, P., Yang, B., Wu, H., Wang, W., Song, H., Huang, B., Zhu, N., Bi, Y., Ma, X., Zhan, F., Wang, L., Hu, T., Zhou, H., Hu, Z., Zhou, W., Zhao, L., Chen, 
J., Meng, Y., Wang, J., Lin, Y., Yuan, J., Xie, Z., Ma, J., Liu, W. J., Wang, D., Xu, W., Holmes, E. C., Gao, G. F., Wu, G., Chen, W., Shi, W., \& Tan, W. (2020). Genomic characterisation and epidemiology of 2019 novel coronavirus: implications for virus origins and receptor binding. Lancet, 395(10224), 565-74.

PMO (Prime Minister Office). (2020a). Restriction of movement order. 14 April 2020. https://www.pmo.gov.my/2020/03/ movement-control-order/

PMO. (2020b). Prihatin Rakyat Economic Stimulus Package (PRIHATIN) Speech
Text. 27 March 2020. https://www.pmo. gov.my/2020/03/speech-text-prihatin-esp/

Star. (April 2020). https://www.thestar.com.my/ news/nation/2020/04/23/five-arrested-forpossession-of-deer-meat-without-permit

Ten, D. C. Y., Edinur, H.A., Jani, R., Hashim, N. H., \& Abdullah, M.T. 2021. COVID-19 and the Malaysian zoo preventive measures readiness. Journal of Sustainability Science and Management, 16(1): 46-54.

WHO (World Health Organisation). (2020). https://www.who.int/health-topics/ coronavirus 